\title{
Sinonasal Adenoid Cystic Carcinoma: Clinical Case Report and Literature Review
}

\author{
Carcinoma Adenoide Quístico Nasosinusal: Caso Clínico y Revisión de la Literatura
}

\author{
Ilson Sepúlveda*; Carolina Delgado*; Paulo Flores ${ }^{\star \star *} \&$ Ornella Salvatori $^{\star \star * *}$
}

SEPÚLVEDA, I.; DELGADO, C.; FLORES, P. \& SALVATORI, O. Sinonasal adenoid cystic carcinoma: clinical case report and literature review. Int. J. Odontostomat., 6(3):296-301, 2012.

ABSTRACT: We present the case of a patient, a 59 year-old man, with Sinonasal Adenoid Cystic Carcinoma. Magnetic resonance exam revealed invasion of the right orbit and brain at the level of the anterior cranial fossa floor. Due to the large volume, we decided to perform radio-chemotherapy treatment to diminish the size of the lesion. On conclusion of the first stage of treatment, reduction in tumor size was confirmed by computerized tomography exam and we decided to perform surgical resection with right ocular globe preservation. At present the patient is under periodic control and without major complications.

KEY WORDS: adenoid, cystic, carcinoma, X-ray, computer tomography, magnetic resonance.

\section{CASE REPORT}

We present the clinical case of a patient, a 59-year-old man, diagnosed by means of biopsy as having Sinonasal Adenoid Cystic Carcinoma with intracranial extension and brain involvement. In T1 sequence of the magnetic resonance (MR) we observed an isointense mass in the ethmoid sinus, infiltrating into the extraconal fat of the right orbit, with lateral displacement of the medial straight muscle associated with ipsilateral exophthalmia (Fig. 1). In T2 sequence, we observed that the mass was shown to be predominantly hyperintense with involvement of brain tissue at the level of the anterior cranial fossa floor (Fig. 2).

In T1 sequence with fat saturation and endovenous paramagnetic contrast we observed marked heterogeneous reinforcement, with hypointense central areas that would correspond to areas of cystic degeneration and/or necrosis. We also observed involvement of the ethmoid, right orbit, nasal fossae and infiltration into the anterior cranial fossa floor (Figs. 3 and 4).

After the case was evaluated by the Head and Neck Oncology Committee, it was decided to perform initial therapeutic management with concomitant radiotherapy and chemotherapy,

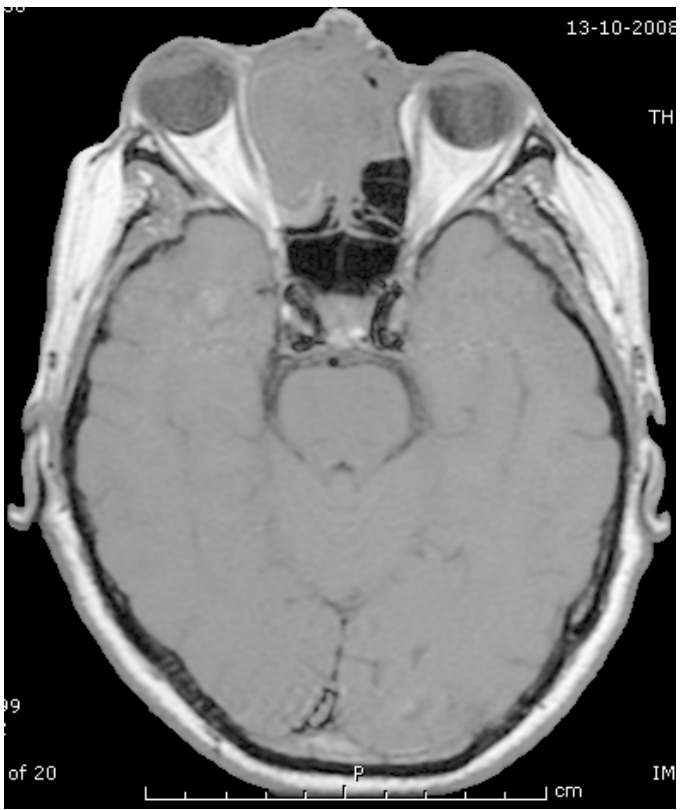

Fig.1. MR T1 - isointense mass in the ethmoid sinus with involvement of right extraconal fat.

* Oral, Maxillofacial-Head and Neck Radiologist. Ear, Head and Neck Cancer Committe, ENT Service, General Hospital of Concepción. Professor of Oral and Maxillofacial Radiology, Finis Terrae University School of Dentistry, Santiago, Chile.

** Physician Pathologist, Pathology Department, Clinical Hospital of Concepción. University of Concepción School of Medicine, Concepción, Chile.

*** Associate Professor, Department of Radiology, School of Dentistry, Federal University of Bahía, Brazil.

**** Undergraduate Student, University of Concepción School of Dentistry, Concepción, Chile. 


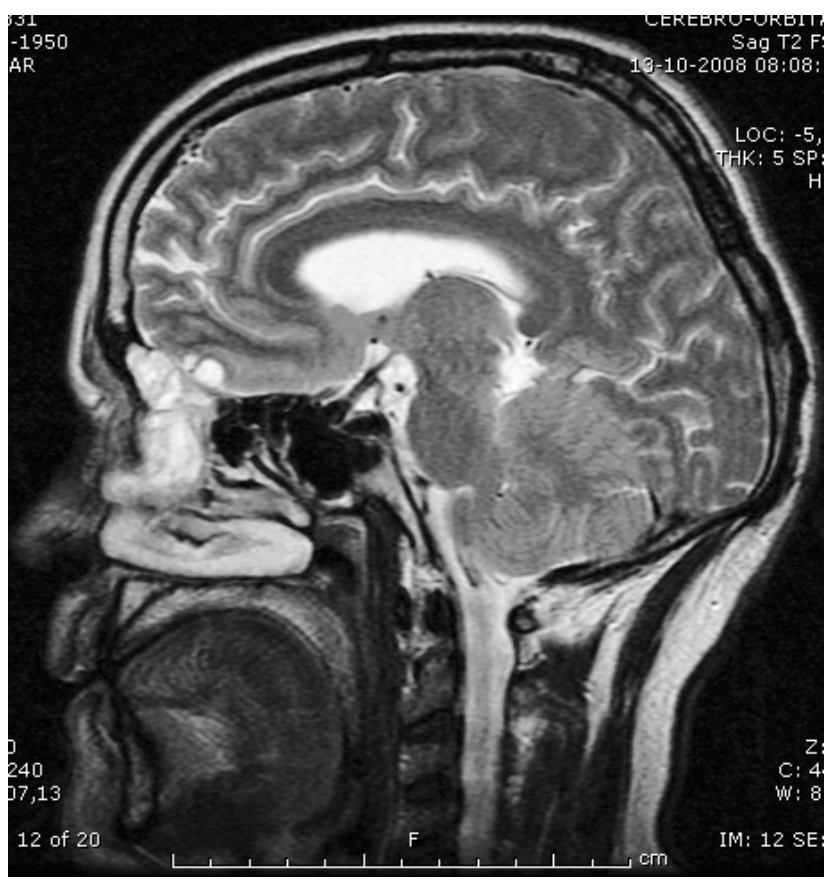

Fig. 2. MR T2 - hyperintense areas at the level of the brain perenchyma.

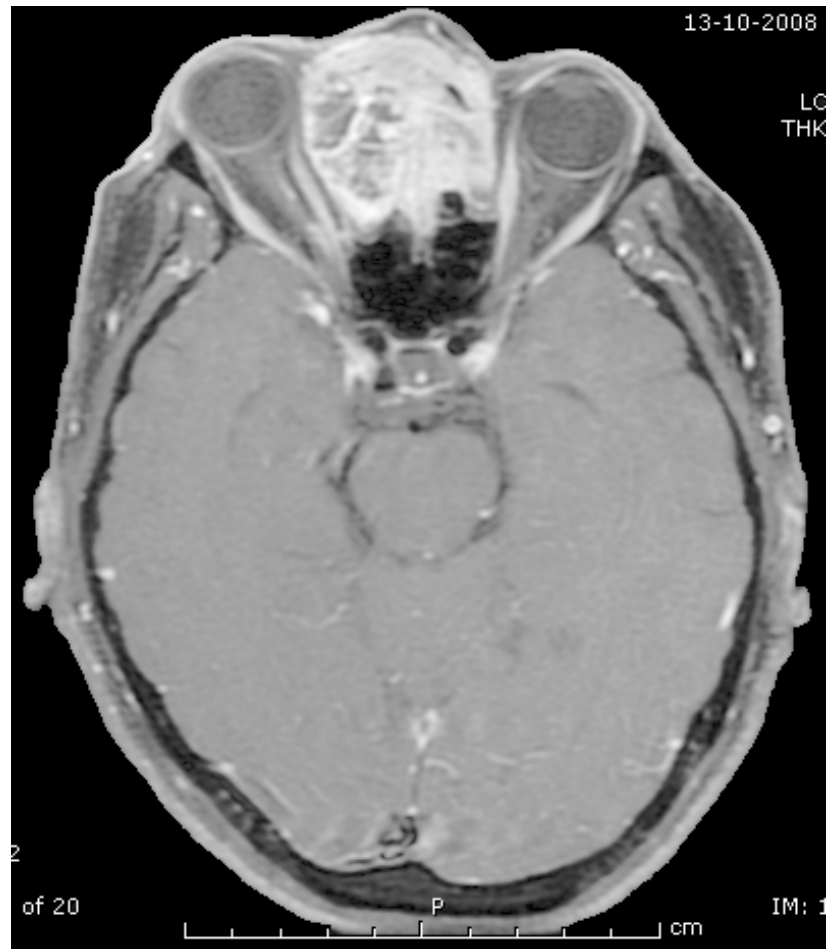

Fig. 3. MR T1 with contrast - marked heterogeneous reinforcement.

due to the extension of the tumor, which prevented initial surgical management. After the first stage of treatment, we verified a partial response of the tumor. Computerized Tomography (CT) showed a reduction

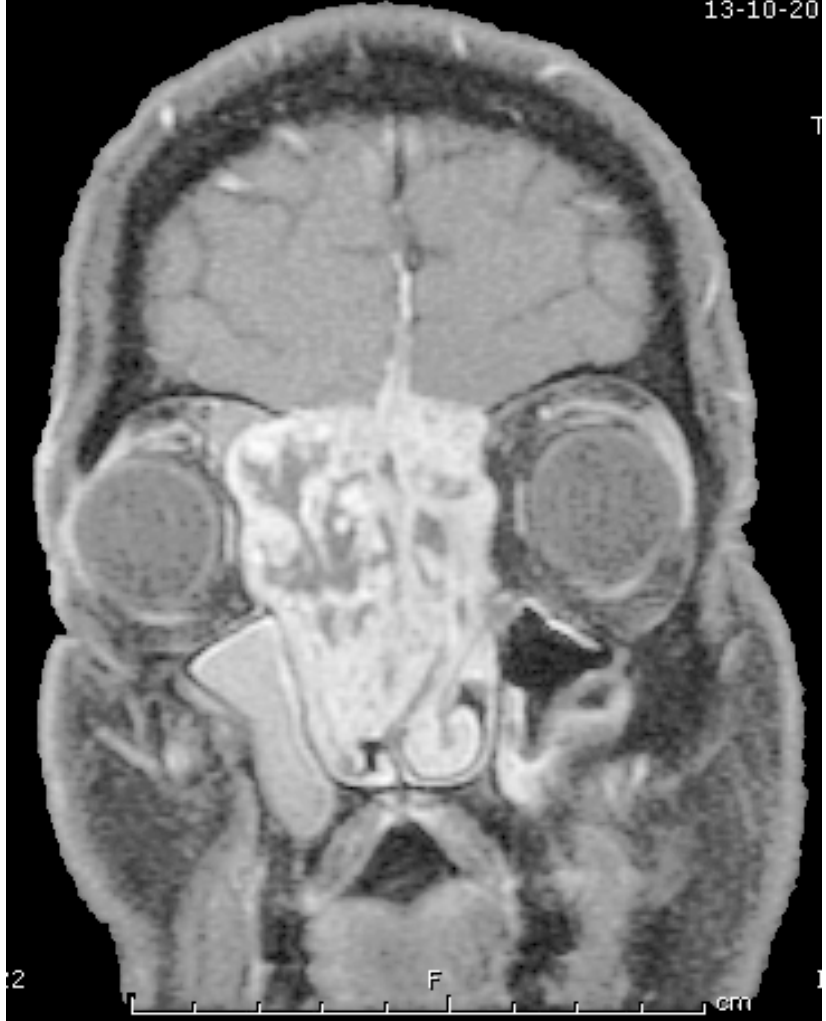

Fig. 4. MR T1with contrast - infiltration into the anterior cranial fossa floor.

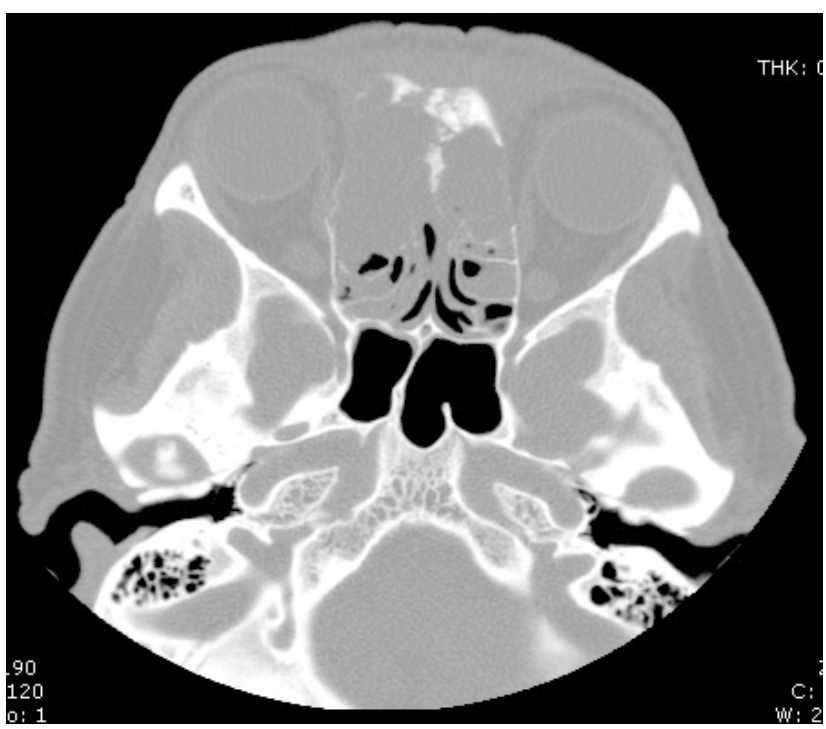

Fig. 5. CT, axial view, with a bone window, showing infiltration of the nasal bones and the papyracea lamina on the right side.

in tumor volume, which maintained its infiltrative characteristics in relation to the lamina papyracea on the right side (Fig. 5). In the CT after the injection of endovenous contrast, we observed heterogeneous 


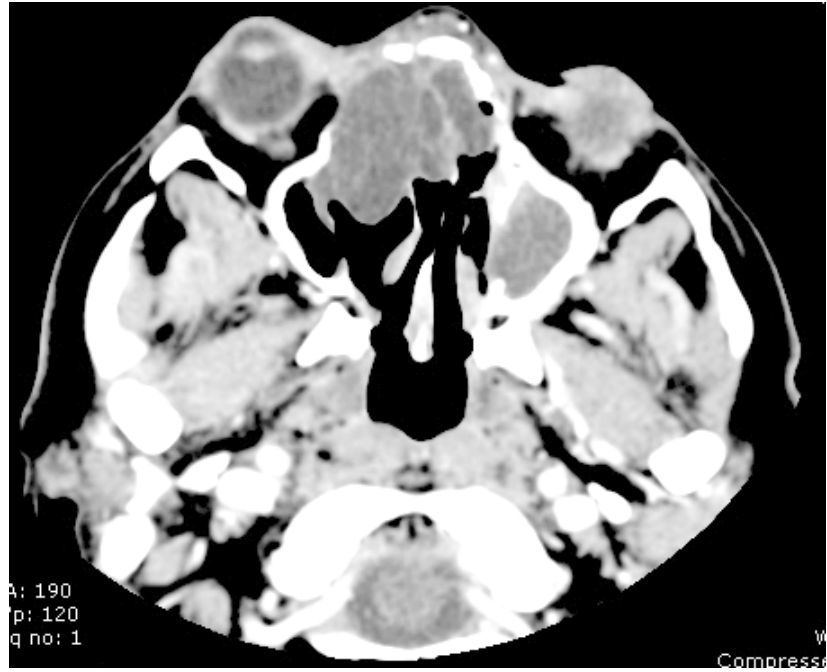

Fig. 6. CT, axial view, with a soft tissue window, revealing a reduction in tumor size in the antero-posterior direction.

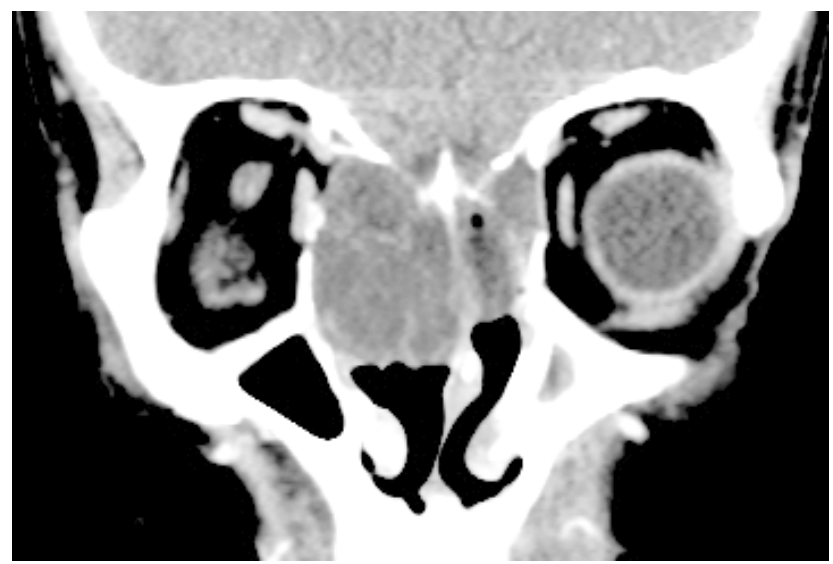

Fig. 7. CT post-contrast, coronal view, with a soft tissue window, showing a heterogeneous mass that occupies the superior half of the nasal fossa.

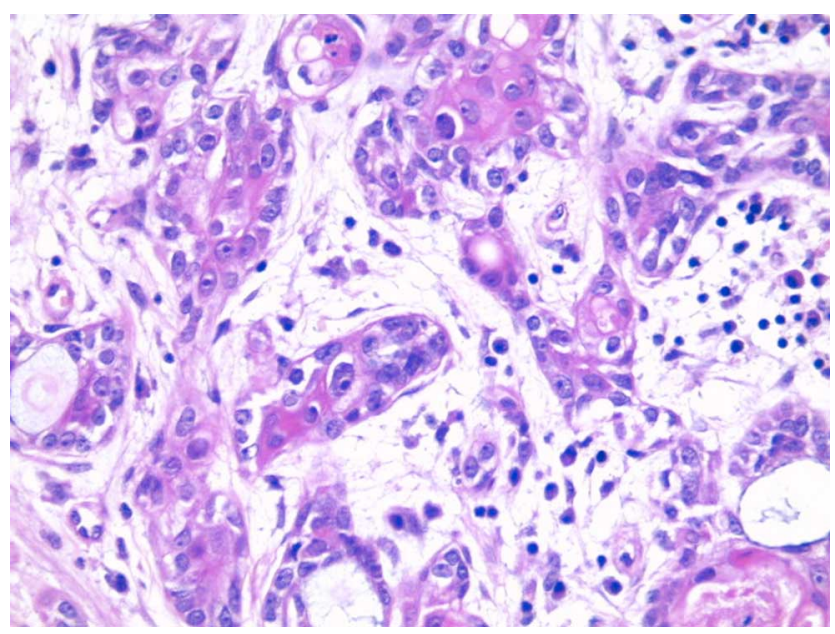

Fig. 8. HE Staining, epithelial cell niches with hyperchromatic nuclei. reinforcement (Figs. 6 and 7). After this we performed a new biopsy of the residual mass, whose result was Adenoid Cystic Carcinoma (ACC).

After a second evaluation by the Oncology Committee, it was decided to perform surgery with a transethmoid approach, with ocular globe preservation. The post-surgical biopsy confirmed the diagnosis of ACC (Fig. 8).

At present the patient is under periodic observation, for eventual control of recurrence. As the surgical procedure resulted in a large cavity in the nasal region, separated from the cranial cavity by only thin layer of soft tissue, there is a high risk of manifestation of a cephalorachidian liquid fistula, which is also under control.

\section{DISCUSSION}

ACC is an uncommon, biologically very aggressive and destructive malignant tumor (Pérusse, 1997 Sequeiros Santiago et al., 2005), that frequently originates in the exocrine glands and is characterized by its high propensity to generate distant metastases (Pérusse; Lupinetti et al., 2007; Rhee et al., 2006; Osborn, 1977; González-García et al., 2006). It was described for the first time by Robin, Lorain and Laboulbene, in two articles published in 1853 and 1854 (Bradley, 2004). Later, Theodor Bilroth described with the name of Cylindroma, in 1856 (Pérusse; Bradley), and Friedmann and Osborn in 1966, denominated it Cribriform Adenocarcinoma, giving a better description of the characteristic of the classical cribriform pattern that indicates the capacity of this neoplasia to behave like a tumor of both epithelial tissue and conjunctive tissue (Osborne). The denomination Adenoid Cystic Carcinoma used at present was introduced by Reid, in 1952.

It represents 0.2 to $0.8 \%$ of all types of cancer and $3 \%$ of tumors of the upper airways. Around $10 \%$ of ACCs jeopardize salivary glands, more frequently (60\%) (Sequeiros Santiago et al., 2005) involving the minor salivary glands (Pérusse; Sequeiros Santiago et al.), with the palate, tongue, oral mucosa and floor of the mouth being the preferential sites (Pérusse).

ACC is ranked the second non-epidermoid epithelial malignant tumor, after adenocarcinoma, frequently appears between the ages of 40 and 60 
years, and affects men and women equally (Riera et al., 2006).

Three histological types are recognized: cribriform, basaloid or solid and tubular (Sequeiros Santiago et al.; Kumar et al., 2003; Bradley). ACC with a tubular pattern is the type that presents the best prognosis; the more common (Lupinetti et al.) cribriform pattern presents an intermediate prognosis; the basaloid pattern presents the highest degree of malignancy, and therefore, the worst prognosis (Sequeiros Santiago et al.; Lupinetti et al.; Bradley).

Of all the malignant tumors of the paranasal sinuses, ACC of the ethmoidal cells represents $10 \%$ of cases (Lupinetti et al.; Ruo Redda et al., 2005) being the most common histological type among the ethmoidal cell tumors (Bimbi et al., 2004) and ranked second among all the sinonasal ACCs, falling behind only ACC of the maxillary sinus (Lupinetti et al.; Ruo Redda et al.).

The sinonasal ACC frequently develops slowly and asymptomatically, and presents nonspecific inflammatory characteristics, which leads to late diagnosis (Sequeiros Santiago et al.; Lupinetti et al.; Gil et al., 2009; Rhee) and low survival rates (Sequeiros Santiago et al.; Gil). Many patients present extension of the tumor into vital structures, such as the duramater, brain, orbit, carotid artery and cranial nerves. In addition, the tumor shows a tendency to infiltrate the perineural tissues (Pérusse; Gil; Rhee et al.; Issing et al., 1999) and develop local post-treatment recurrence and late distant metastases (Lupinetti et al.; Rhee et al.; Osborn; González-García et al.; Bradley).

Symptoms related to sinonasal ACC are highly variable (Pérusse), but patients commonly relate symptoms such as nasal obstruction $(60-90 \%$ of cases), epistaxis (20-50\%); rhinorrhea (50\%), facial pain, headache and paresthesia (Pérusse; González-García et al., 2006).

Distant metastases may be found in the lungs (most frequently), bones, liver and brain, in many cases occurring decades after treatment. Metastasis to the lymph nodes is very uncommon (Kumar et al.). Distant metastasis appears to be an important factor in determining the survival rate. The survival rate at 5 and 10 years, of patient without metastases is $100 \%$ and $69 \%$, respectively. However, the survival rate at 5 and 10 years, of patient with distant metastases is $58 \%$ and $29 \%$, respectively. The mean survival time of patients with distant metastasis is 25 months, and only $17 \%$ of these patients have a survival time longer than 5 years (Rhee et al.).

There are reports showing that patients with ACC close to the base of the skull present a significantly increased risk of local recurrence, in view of the difficulty of achieving adequate safety margins, due to the difficulty of the surgery, extension of the tumor into the intracranial nerves and restriction of the limits of resection imposed by the proximity of neural and vascular structures (Kumar et al.). Approximately 50\% of recurrences are clinically evident 2 years after surgery and radiotherapy.

The treatment of choice for ACC that compromises the base of the skull is radical surgery combined with radiotherapy (Lupinetti et al.; Kumar et al.; Bradley; Riera et al.) and many authors agree that when there is involvement of the base of the skull in cases of ethmoidal ACC, resection of the tumor must be performed in blocks (Rhee et al.). The scope of the surgery must be as wide as possible and demands broad and modulable surgical access, according to the extension of the tumor. Post operative radiotherapy increases local control, and therefore, survival (Riera et al.).

CT and MR, with and without endovenous contrast are commonly used to determine the margins, extension and tumor infiltration pattern, as well as to determine perineural invasion at the base of the skull. Metastasis and extension into various structures are generally evaluated by means of radiographs, echotomography and scintillography (Lupinetti et al.; Issing et al.). Thus, imaging exams are doubtlessly one of the key therapeutic and post treatment control strategies.

SEPÚlVEDA, I.; DELGADO, C.; FLORES, P. \& SALVATORI, O. Carcinoma adenoide quístico nasosinusal: caso clínico y revisión de la literatura. Int. J. Odontostomat., 6(3):296-301, 2012.

RESUMEN: Se presenta el caso de un paciente de sexo masculino de 59 años con carcinoma adenoide quístico nasosinusal. El examen de resonancia magnética reveló la invasión de la órbita derecha y el cerebro a nivel del suelo de la fosa craneal anterior. Debido al gran volumen, se decidió realizar el tratamiento de radio-quimioterapia para disminuir el tamaño de la lesión. Al término de la primera etapa del tratamiento, la reducción del tamaño del tumor fue confirmada por el examen de tomografía computarizada y se decidió realizar una resección quirúrgica con preservación 
del globo ocular derecho. En la actualidad el paciente se encuentra bajo el control periódico y sin mayores complicaciones.

PALABRAS CLAVE: adenoide quístico, carcinoma, rayos $X$, tomografía computarizada, resonancia magnética.

\section{REFERENCES}

Bimbi, G.; Saraceno, M. S.; Riccio, S.; Gatta, G.; Licitra, L. \& Cantù, G. Adenocarcinoma of ethmoid sinus: an occupational disease. Acta Otorhinolaryngol. Ital., 24(4):199-203, 2004.

Bradley, P. J. Adenoid cystic carcinoma of the head and neck: a review. Curr. Opin. Otolaryngol. Head Neck Surg., 12(2):127-32, 2004.

Gil, Z.; Carlson, D. L.; Gupta, A.; Lee, N.; Hoppe, B.; Shah, J. P. \& Kraus, D. H. Patterns and incidence of neural invasion in patients with cancers of the paranasal sinuses. Arch. Otolaryngol. Head Neck Surg., 135(2):173-9, 2009.

González-García, R.; Escorial Hernández, V.; Martos, P. L.; Mancha de la Plata, M.; Naval Gías, L.; Rodríguez Campo, F. J.; Sastre Pérez, J.; Muñoz Guerra, M.; Hinojar, A. \& Gamallo, C. Adenocarcinoma de mucosa etmoidal. Abordaje quirúrgico mediante rinotomía lateral. Rev. Esp. Cirug. Oral Maxilofac., 28(1):57-61, 2006.

Issing, P. R.; Hemmanouil, I.; Stöver, T.; Kempf, H. G.; Wilkens, L.; Heermann, R. \& Lenarz, T. Adenoid cystic carcinoma of the skull base. Skull Base Surg., 9(4):271-5, 1999.

Kumar, V. P.; Rao, P. N. \& Kumar, G. A. Adenoid cystic carcinoma of nasal cavity - a case report. Indian J. Otolaryngol. Head Neck Surg., 55(1):43-6, 2003.

Lupinetti, A. D.; Roberts, D. B.; Williams, M. D.; Kupferman, M. E.; Rosenthal, D. I.; Demonte, F.; El-Naggar, A.; Weber, R. S. \& Hanna, E. Y. Sinonasal adenoid cystic carcinoma: the M. D. Anderson Cancer Center experience. Cancer, 110(12):2726-31, 2007.

Osborn, D. A. Morphology and the natural history of cribriform adenocarcinoma (adenoid cystic carcinoma). J. Clin. Pathol., 30(3):195-205, 1977.
Pérusse, R. Adenoid cystic carcinoma of the maxillary sinus. J. Am. Dent. Assoc., 128(11):1551-5, 1997.

Ruo Redda, M. G.; Succo, G.; Guarneri, A. \& Ragona, R. Radiotherapy after surgery for advanced adenoid cystic carcinoma of paranasal sinus. Lancet Oncol., 6(12):994-6, 2005.

Rhee, C. S.; Won, T. B.; Lee, C. H.; Min, Y. G.; Sung, M. W.; Kim, K. H.; Shim, W. S.; Kim, Y. M. \& Kim, J. W. Adenoid cystic carcinoma of the sinonasal tract: treatment results. Laryngoscope, 116(6):982-6, 2006.

Riera, C.; Aldasoro, J.; Marcote, J.; Martínez Benaclocha, M. \& Gozalbo, J. M. Carcinoma adenoide quístico nasal. O.R.L.-DIPS, 33(1):28-30, 2006.

Sequeiros Santiago, G.; Rodrigo Tapia, J. P.; Llorente Pendás, J. L. \& Suárez Nieto, C. Factores pronósticos en el carcinoma adenoide quístico de glándulas salivares. Acta Otorrinolaringol. Esp., 56(8):361-7, 2005.

Correspondence to:

Dr. Ilson Sepúlveda

Servicio de Otorrinolaringología, Cabeza y Cuello

Hospital Clínico Regional de Concepción

San Martín No 1436

Concepción

CHILE

Email:isepulvedaguilar@gmail.com

Received: 08-03-2012

Accepted: 23-04-2012 